Nr. 2, sept. 2018, 133.-152. lpp. doi: 10.7250/IAV.2018.011

\title{
RĪGAS POLITEHNISKĀ INSTITŪTA ABSOLVENTS AGRONOMS BORISS JENKENS (1873-1943)
}

\section{VIKTORS VERGUNOVS*}

Ukrainas Nacionālās agrārās zinātnes akadēmijas Nacionālā zinātniskā lauksaimniecības bibliotēka

Kopsavilkums. Raksts veltīts Rīgas Politehniskā institūta (RPI) absolventa (1900) agronoma Borisa Jenkena (Борис Карлович Єнкен; 1873-1943) dzīvei un radošajam mantojumam. B. Jenkens bija Ukrainas nacionālās lauksaimniecības organizators, zinātnieks, selekcionārs, pedagogs, vēsturnieks un agrārās zinātnes bibliogrāfs. Pētījums veikts, izmantojot maz zināmus un nesen plašākai publikai lietošanai nodotus dokumentus Krievijas Federācijas un Ukrainas arhīvos, kā arī monogrāfijas un publikācijas periodiskajos izdevumos. Rakstā analizēti zinātnieka dzìves un darbības periodi, kas skar nacionālās lauksaimniecības izmēǵinājumu organizāciju un ieviešanu galvenokārt selekcijas un sēklaudzēšanas jomā. Akcents likts uz B. Jenkena zinātniski pedagoǵisko darbību Ukrainā: Harkovā (1908-1919; 1925-1926; 1930), Odesā (1924), Maslovkā (1927-1929) un Kijevā (1928-1929).

Atslēgas vārdi: Rīgas Politehniskais institūts, Boriss Jenkens, agronomija 20. gadsimta pirmajā pusē Ukrainā.

\section{Borisa Jenkena gimene un darbība cariskajā Krievijā}

Boriss Jenkens piedzima 1873. gada 24. (pēc vecā stila 12.) janvārī Tambovas pilsētā pazīstama vācu un zviedru izcelsmes jurista (zvērināta advokāta) Karla Jenkena (Карл Августович Єнкен) ǵimenē. Māte Olga Jenkena (dz. Švidkovska) (Ольга Федорівна Єнкен) bija dzimusi Poltavā muižnieku ǵimenē [1]. B. Jenkens 1892. gadā pabeidza reālskolas septinnas klases Tambovā. No 1893. gada sešus gadus vin̄š studēja Rīgas Politehnikuma (RP), kas 1896. gadā tika reorganizēts par Rīgas Politehnisko institūtu (RPI), Lauksaimniecības nodaḷā.

\footnotetext{
* Korespondējošais autors.

E-pasts: nnsgb@ukr.net
} 
1. attēls. Boriss Jenkens (ap 1890) [2].

Studiju laikā B. Jenkens aizrāvās ar revolucionārām idejām. 1895. gadā par nelegālas literatūras glabāšanu un izplatīšanu vinšs noklıuva policijas uzraudzībā un uz laiku tika atskaitīts no augstskolas [3]. B. Jenkena atskaitīšanas faktu «sakarā ar apsūdzību noziegumā pret valsti» Izglītības ministrijas kancelejas vadītājs apstiprināja 1897. gada 20. decembrī. Borisam Jenkinam tika liegta «iestāšanās jebkurā mācību iestādē», kā arī nodarbošanās ar pedagoǵisko praksi [4]. Tikai pateicoties tam, ka notiekošajā iejaucās tēvs, situāciju izdevās atrisināt. 1900. gada 29. janvārī vin,š absolvēja RPI ar diplomu Nr. 106 un uzslavas atestātu Nr. 419, kas datēts ar 1900. gada 27. martu [5].

RPI Ķìmijas nodaḷā 1897. gadā sāka studēt arī Karla brālis Fjodors Jenkens (1875-?), kurš no augstskolas par studiju naudas nesamaksāšanu tika atskaitīts 1901. gada septembrī [6]. Otrs Karla brālis Sergejs Jenkens (1876-1962) bija pazīstams fotogrāfs Tambovā.

Pēc RPI absolvēšanas B. Jenkens devās uz Krievijas dienvidiem un gadu pētīja Kubañas apgabala lauksaimniecību, organizēja vīndaru saimniecību netālu no Anapas. Saskaṇā ar Saratovas guberṇas Petrovskas Zemstes pārvaldes 1900. gada 20. februāra nolīgumu viṇš strādāja par apriṇķa agronomu. Šeit viṇš pirmo reizi pieteica sevi kā spilgtu nacionālās sabiedriskās agronomijas pārstāvi. Jāpiebilst, ka tieši šajā periodā agronomija sāka intensīvi attīstīties. 1902. gada 27. jūlijā Saratovas gubernas Zemstes pārvaldes agronomu sapulcē B. Jenkens referēja par lauksaimniecības izmēǵinājumu sistēmas organizāciju guberñā [7]. Referātu publicēja sapulces materiālu krājumā, un tam pievērsa uzmanību speciālisti. Sākot no 1903. gada 3. janvāra, saskaṇā ar Saratovas guberñas Voḷskas Zemstes pārvaldes lūgumu viṇš kḷuva par zemstes agronomu. 1903. gada 1. novembrī Tambovas apriṇka Zemstes pārvalde lūdza gubernatoram norīkot B. Jenkenu par savu agronomu. Nesaṇemot atbildi divu nedēlu laikā, kā to paredzēja likums, 1903. gada 8. decembrī pārvalde savā sapulcē pieñēma lēmumu uzticēt viṇam agronoma pienākumus ar 100 rubḷu atalgojumu mēnesī [8]. Šajā amatā B. Jenkens aktīvi propagandēja un izplatīja jaunākās atziṇas agronomijā. Par to liecina 
Tambovas apriṇka Zemstes pārvaldes 1904. gada 6. oktobra ziṇojums, ka «agronoms Jenkens sava neilgajā dienesta laikā nodemonstrējis lielu aktivitāti un pēc paša iniciatīvas šajā gadā veica sēju ar rindu sējmašĩnām un demonstrēja Mak-Kormika plaujmašīnu vairākās vietās pie īpašniekiem un zemniekiem, kas neapšaubāmi nesa daudz labuma.» Tambovas apriṇk Zua Zemstes pārvaldes sēdē 1905. gada 1. oktobrī tika atzīmēts, ka agronoms B. Jenkens pilnā mērā ir nopelniem bagāts cilvēks, kuru visi ciena [9]. 1904. un 1905. gadā B. Jenkens sagatavoja virkni zinnojumu un rakstu par nepieciešamību uzlabot agronomiskās palīdzības organizāciju. Vairāki viṇa raksti publicēti avīzē «Тамбовский голод» («Tambovas Bads»), kurā viṇš bija viens no dibinātājiem (1904) un trim redaktoriem. Neskatoties uz lielo ieguldījumu savā dzimtenē, pēc gubernatora prasības 1905. gada 9. februārī viṇu kā personu, kas ir iepriekš «.. sevi sakompromitējusi kā politiski neuzticamu», atbrīvoja no darba. Šajā situācijā B. Jenkens vērsās pie Tambovas apriṇk, muižniecības vadītāja Vasilija Petrovo-Solovovo (Васи́лий Миха́йлович Петрово́Соловово́; 1850-1908) ar vēstuli, kurā ziṇoja par nolūku vērsties pie apriṇka zemstes sapulces «ar lūgumu uzklausīt mani un atjaunot zemstes darbinieka tiesības.» Sapulce, izskatot B. Jenkena rakstisko lūgumu, savā sēdē 1905. gada 2. oktobrī nolēma: «Izteikt sūdzību valdības Senātam par Tambovas gubernatora rīcību, atbrīvojot no dienesta zemstes agronomu Jenkena k-gu [10].»

1905. gada 4. maijā B. Jenkens pēc Atkarskas apriṇķa zemstes ielūguma sāka strādāt par agronomu, bet decembrī viṇu uz četriem mēnešiem apcietināja par dalību 1905. gada revolūcijā, jo viṇš uzstājās mītinā un publicēja avīzē tā lēmumus [11]. Pēc tam viṇš neilgi uzturējās ārzemēs [12].

No 1906. gada oktobra līdz 1907. gada jūnijam B. Jenkens veica Saratovas apriṇķa Zemes nodaḷas guberñas agronoma pienākumus. Šajā amatā kopā ar citiem zinātniekiem viṇš aktīvi piedalījās augsnes klimatiskajos pētījumos un risināja organizatoriskus jautājumus, kas saistīti ar slavenās Saratovas izmēǵinājumu stacijas radīšanu (tagad - valsts mācību iestāde «Dienvidaustrumu Lauksaimniecības zinātniskās pētniecības institūts»). Oficiāli stacija darbību sāka 1910. gada 15. martā. Zinātnieks publicēja vairākus rakstus par problemātiskiem jautājumiem Saratovas guberñas žurnālos un pilsētas laikrakstā «Земская газета» («Zemstes Avīze»). Ieņemamo amatu B. Jenkens atstāja pēc tam, kad vinu turpmākajam periodam tajā neapstiprināja Saratovas gubernators. Tāpēc līdz 1908. gada maijam B. Jenkins bija spiests vadīt vīna ražošanas uzṇēmu Anapā.

1909. gadā B. Jenkinu atkal notiesāja - pēc Saratovas Tiesu palātas lēmuma viṇš apcietinājumā bija vienu gadu, no 1909. gada 29. decembra līdz 1910. gada 29. decembrim. 
No 1908. gada 1. maija līdz 1919. gada 19. jūlijam B. Jenkena zinātniskā darbība bija saistīta ar Harkovas Lauksaimniecības un lauksaimnieciskās rūpniecības biedrību. Vispirms vinu ievēlēja par direktora vietnieku biedrības dibinātajā Eiropā pirmajā specializētajā selekcijas stacijā Harkovā. Viṇš piedalījās visos stacijas sagatavošanas darbos (meklēja izmēǵinājumiem piemērotus laukus, izstrādāja programmas, lika pamatus stacionārajiem izmēginājumiem, piedalījās celtniecībā utt.) [13]. Zinātnieks piedalījās Harkovas Selekcijas stacijas komitejas izveidē. Tās organizatori, kopā 21 persona, bija iecerējuši, ka 1913. gadā stacija kḷūs par Harkovas apgabala Lauksaimniecības izmēǵinājumu stacijas (LIS) pirmo nodalı.

1908. gada 17. decembrī pēc guberņas entomologa I. Jemeḷjanova (И. В. Емельянов) uzstāšanās ar referātu «Cīṇa ar kaitēkḷiem Savienotajās Valstīs» Harkovas Lauksaimniecības biedrības (HLB) kopsapulcē tieši B. Jenkens kopā ar A. Rabinoviču (А. М. Рабинович) iniciēja «.. motivētu lūgumu Galvenajai zemes ierīcības un zemkopības pārvaldei dibināt entomoloǵijas staciju Harkovas tuvumā» [14]. Turklāt zinātnieks avīzes «Южно-Русская сельскохозяйственная газета» («Dienvidkrievijas Lauksaimniecības Avīze») 1909. gada 56. numurā publicēja aicinājumu piegādāt ziemāju un vasarāju sēklas. Šim nolūkam viṇš izmantoja arī personiskos kontaktus un vērsās izmēginājumu iestādēs. Bez tam B. Jenkens personīgi nodarbojās «.. ar 100 tūkstošu ķieǵel̦u sagādi» .. «turpmākām celtniecības vajadzībām», tāpat viṇš nodarbojās arī ar «.. dzīvā un nedzīvā inventāra» un auzu iegādi [15].

Paralēli galvenajām funkcijām B. Jenkens gatavoja rakstu 14 sējumu un 21 grāmatas izdevumam «Zinātnisko un praktisko zinību nacionālā enciklopēdija» (1910-1912). B. Jenkins gatavoja enciklopēdijas 4. sējuma «Lauksaimniecība» 2. dal̦u «Zemkopība» ar profesora Pjotra Budrina (Пётр Васильевич Будрин; 1857-1939) priekšvārdu. Enciklopēdijas iniciators bija Harkovas Lasītprasmes izplatīšanas biedrība ar nolūku veicināt iedzīvotāju izglītotību [16]. Izdevuma, kas bija veltīts minētās biedrības 40 gadu jubilejai (1869-1909), sagatavošanā piedalījās vairāk nekā 100 zinātnieku, un tas tika veidots pēc franču enciklopēdijas principa. Kopā ar stacijas direktoru P. Budrinu B. Jenkens kḷuva par aktīvu 1. Krievijas selekcionāru un graudkopju kongresa dalībnieku, kas no 1911. gada 10. līdz 15. janvārim norisinājās Harkovā [17]. Pēc kongresa orgkomitejas lūguma viṇš uzstājās ar vairākiem fundamentāliem referātiem, kas tika publicēti [18]: 1) «Selekcija un tās nozīme ārzemju valstīs (īss vēsturisks apskats un mūsdienu zinātniskās un praktiskās selekcijas apkopojums Rietumeiropā un Ziemel̦amerikas Savienotajās Valstīs)» - ar šo referātu viṇš kḷuva par pirmo šāda virziena pašmāju vēsturnieku; 2) «Lauksaimniecības augu selekcijas organizācijas jautājums Krievijā», kurā autors piedāvāja izveidot organizētu selekcijas 
sistēmu; 3) «Selekcijas staciju kontrolētas darbības jautājums», kurā tika runāts par svarīgākajiem selekcijas staciju uzdevumiem selekcijas jomā; 4) «Par Dienvidkrievijas lauksaimniecības augu un graudkopības selekcijas biedrības izveidi HLB ietvaros», 5) «Nepieciešamība organizēt Krievijas kongresus dažādās izmēǵinājumu jomās un organizēt kongresus (komitejas) dažādos reǵionos», ar šo referātu B. Jenkens nodemonstrēja savu metodologa pieredzi, organizējot nacionālo izmēǵinājumu jomu. Kongresa laikā viṇš iepazinās ar pasaulslaveno krievu genētiḳi, botāniki, selekcionāru Nikolaju Vavilovu (Никола́й Ива́нович Вави́лов; 1887-1943), ar kuru vēlāk sarakstījās, savukārt B. Jenkena vecākais dēls kluva par N. Vavilova skolnieku.

Pēc kongresa HLB valde 1911. gada 19. janvārī pēc biedrības prezidenta S. Kuzn,ecova (C. М. Кузнецов) ziṇojuma nolēma B. Jenkenu sūtīt komandējumā uz Vāciju, Austriju, Dāniju un Zviedriju, lai viṇš tur iepazìtos ar selekcijas iestāžu un graudu saimniecību organizāciju un metodiku, kā arī ar selekcijas un graudu tirdzniecības pieredzi. Šim nolūkam biedrība pieškīira 900 rubl̦us, bet 2000 rubḷus - Zemkopības departaments. Vēl pirms aizbraukšanas 1911. gada 2. februārī B. Jenkens sañēma atbalstu no HLB Harkovas selekcijas stacijas augḷu un dekoratīvā dārzu ierīkošanai [19]. Būdams ārzemēs no 1911. gada 16. marta līdz 5. jūnijam un no 1911. gada 1. septembra līdz 1912. gada 19. februārim, viṇš strādāja Rūgšanas vielu un cietes institūtā, Maizes pārstrādes izmēginājumu stacijā Berlīnē, kā arī selekcijas stacijās Hallē, Vācijā un Svalefi, Zviedrijā. Turklāt divus semestrus viṇš mācījās Halles Universitātes Lauksaimniecības nodaḷā. No 1911. gada 18. līdz 22. septembrim viṇš piedalījās 4. starptautiskajā genētikas konferencē Parīzē kā vienīgais delegāts no Krievijas [20]. B. Jenkens apmeklēja alus darītavu izstādi Berlīnē. Stažēšanās rezultātu HLB vārdā viṇš apkopoja brošūrā «Письма из заграницы (заметки селекционера)» («Vēstules no ārzemēm (selekcionāra piezīmes)» [21]. Pēc atgriešanās dzimtenē 1911. gadā 31. augustā viṇš rakstīja vēstuli Krievijas zemkopības un valsts īpašumu ministrijas Lauksaimniecības zinātniskās komitejas Lietiškās botānikas biroja vadītājam botāniķ̣im Robertam Regelam (Ро́берт Эдуа́рдович Ре́гель; 18671920), apstiprinot savu vēlmi turpināt 1910. gadā sākto sadarbību [22].

B. Jenkens iekaroja milzīgu autoritāti un cieṇu profesionālās aprindās, pārstāvot Harkovas Selekcijas staciju ar fundamentālu referātu «Izmēgénājumu prakses attīstība Krievijā un tās patreizējais stāvoklis» Poltavas Lauksaimniecības biedrības sēdē 1909. gada 28. oktobrī. Sēdi organizēja Poltavas Lauksaimniecības biedrība, un tā bija veltīta Poltavas izmēǵinājumu lauka 25. gadadienai. B. Jenkena referātu nopublicēja sēdes rakstu krājumā, kā arī 1912. gadā izdeva Poltavā kā brošūru tūkstots eksemplāru tirāžā. Zinātnieks kḷuva par pirmo klasisko vēsturnieku savā dzimtenē, kurš specializējas lauksaimniecības izmēǵinājumu 
jomā. No 1912. gada 20. līdz 26. janvārim viṇš piedalījās apgabala kongresā Pēterburgā, kas bija veltîts selekcijas un sēklkopības jautājumiem [23], bet no 24. līdz 26. jūnijam - pirmajā kongresā Rostovā pie Donas, kas bija veltīts lauksaimniecības izmēǵinājumu praksei Dienvidaustrumeiropas Krievijā un Ziemel̦kaukāzā [24]. No 1913. gada 11. līdz 12. februārim B. Jenkens piedalījās sapulcē Pēterburgā, kas bija veltīta lauksaimniecības izmēǵinājumu praksei. Zinātnieks teorētiski pamatoja nepieciešamību veidot speciālas savvaḷas un vietējo lauksaimniecības augu audzētavas selekcijas un izmēǵinājumu stacijās [25]. Līdz ar to vin,š faktiski lika pamatus mūsdienu genētisko datu bankām. Jāpiebilst, ka tagad šo funkciju Ukrainā pilda Harkovas Selekcijas stacijas tradīciju turpinātājs V. Jurjeva vārdā nosauktais Augkopības institūts. Turklāt minētajā sapulcē spraigā diskusijā ar jau minēto R. Regelu, kā arī selekcionāru Viktoru Talanovu (Виктор Викторович Таланов; 1871-1936) un citiem B. Jenkens pierādīja, ka speciālas maltuvju laboratorijas graudu kvalitātes novērtēšanai ir nepieciešams ierīkot ne tikai Imperatora lauksaimniecības muzejā, bet katrā selekcijas stacijā vai apgabala lauksaimniecības stacijas selekcijas nodaḷā. Vinš pats personiski radīja virkni tādu laboratoriju Ukrainā: Odesā, Maslovkā, Kijevā.

1913. gada septembrī B. Jenkens piedalījās Pirmajā Krievijas lauksaimniecības kongresā Kijevā ar trim referātiem: «Individuālās un masu atlases nozìme un metodika», «Krustošanas uzdevums Krievijas apstākḷıs» un «Lauksaimniecības augu šķirnu izpētes neatliekamais uzdevums» [26; 27]. Kongresā viṇu vispirms ievēlēja par priekšsēdētāja vietnieku, bet pēc sestās zemkopības sekcijas sēdes viṇš kḷuva par tā prieksšsēdētāju. Pēc P. Budrina pārcelšanās uz Pēterburgu 1912. gadā B. Jenkens līdz 1913. gadam pildīja Harkovas Selekcijas stacijas direktora pienākumus.

1913. gadā staciju reorganizēja, pievienojot to kā apakšnodaḷu Harkovas apgabala Lauksaimniecības izmēǵinājuma stacijai. B. Jenkens kḷuva par tās Selekcijas nodạlas vadītāju, bet, sākot no 1914. gada, vinš̌ slimoja ar tuberkulozi un strādāja par vienkāršu zinātnisko līdzstrādnieku [28]. Viņš ne tikai veica milzīgu organizatorisku darbu, lai veicinātu stacijas attīstību, bet arī nodarbojās ar selekciju sava skolotāja profesora P. Budrina vadībā, kḷūstot par pionieri zinātnieku vidū, strādājot ar saulespuksēm (no 1909). Ne velti, kad saulespuḳu kultūras selekcionāram Vasilijam Pustovoitam (Васи́лий Степа́нович Пустово́йm; 1886-1972) 1912. gadā jautāja, kāpēc viṇš grib ar to nodarboties, viņš atbildēja, ka ar to nodarbojas tikai divi zinātnieki Jevgēnija Plačeka (Евгения Михайловна Плачек; 1878-1955) Saratovā un Boriss Jenkens Harkovā. Jāpiebilst, ka pirmie saulespuksu pētījumi ir jādatē ar 1895.-1896. gadu, ko iniciēja Zemkopības departaments Lohvickas izmēǵinājuma laukā Poltavas apgabalā departamenta direktora 
P. Lomonosova (П. М. Ломоносов) vadībā. Lielākie panākumi šajā jautājumā tika sasniegti, sākot no 1905. gada [29].

1912. gada 16. martā HLB vārdā B. Jenkens stacijā noorganizēja un līdz savai aizbraukšanai no Harkovas vadīja valstī pirmo nozari koordinējošo orgānu - Lauksaimnieciskās augkopības komiteju. Vinšs paveica milzīgu eksperimentālo selekcijas darbu Harkovas izmēginājumu stacijā. Par viṇa genētiskās, metodoloǵiskās un selekcijas darba objektiem līdzās saulespuksēm kḷuva arī ziemas rudzi un mieži. Attiecībā uz rudziem zinātnieks beidza savus pētījumus, izveidojot vārpu klasifikāciju, kā arī dodot tiem botānisku un agronomisku raksturojumu. 1914. gadā viṇš iniciēja ne tikai Krievijas impērijā, bet arī visā pasaulē progresīvus ekspedīcijas pētījumus no botāniskā un agrobioloǵiskā viedokḷa Harkovas guberñā pēc Harkovas guberṇas zemstes pasūtījuma. Šajā pētījumā tika konstatēts 231 ziemāju kviešu paraugs, lielāka daḷa no tiem piederēja pie sarkanā bezakota tipa. Šīs darbības laikā vinšs aprakstīja arī regiiona un origínālās ārzemju rudzu kultūras škirnes. Neskatoties uz to, ka vēlāk saulespuḳu kultūras vēsturnieki uzskatīja B. Jenkena mēginājumus palielināt eḷlas daudzumu sēklās par neveiksmīgiem [30], viņš beidza pētījumu par pašapputeksn,ošanas ietekmi un sāka noskaidrot, kādai ir jābūt videi, kas nodrošinātu saulespuḳu izolāciju. Turklāt pirmo reizi Ukrainā tika radītas pašmāju saulespuḳu šķirnes 'Zel̦onka' ('Harkovas 76') un 'Harkovas 27-82', kas veiksmīgi aizstāja mazražīgās un maz ellıu dodošās šksirnes. Tās tika zonētas 1927. un 1930. gadā [31]. Veicot selektīvos izmēǵinājumus ar saulespuḳēm, zinātnieks ieguva lielu daudzumu perspektīva šīs kultūras materiāla. Bez tam B. Jenkens kopā ar citiem selekcionāriem radīja jaunu ziemāju rudzu šksirni 'N̦emišlanska 953', kas tika zonēta 1923. gadā. B. Jenkens nodarbojās arī ar Pernauskas rudzu selekciju kā arī citām. Par galveno atlases pazīmi kḷuva: stiklveida graudi, īsie salmi un vārpas tips $\mathrm{S}$ «plakans, liras formas un B». Tika sākta 'N̦emišl̦anskas' un 'Perkusa' škirnes rudzu krustošana un pabeigta mēslojuma ietekmes izpēte uz tiem. 1912. gadā B. Jenkens izveidoja koncepciju un sagatavoja jauna zinātniskā žurnāla pirmo numuru, veltītu HLB selekcijai un sēklkopībai «Сельскохозяйственное растениеводство юга России» («Krievijas Dienvidu Lauksaimnieciskā Augkopība»), kas līdzekḷu trūkuma un, galvenais, zinātnieka slimības dēl netika izdots.

B. Jenkens no 1914. gada 1. jūlija līdz 1915. gada 5. maijam ārstējās ārzemēs. Atgriezies Krievijā, 1915. gada jūnijā vin,š vēlējās kḷūt par Harkovas apgabala lauksaimniecības stacijas Selekcijas nodaḷas vadītāja palīgu, taču politisku iemeslu dēl viṇam amatu atteica.

Citu rezultatīvu B. Jenkena sasniegumu vidū jāmin sēklu un graudu glabātavas projekta izstrāde pēc labākajiem Eiropas standartiem pēc HLB pasūtījuma vietējai apgabala lauksaimnieciskajai selekcijas 
stacijai. HLB kopš 1896. gada izdeva laikrakstu «Южно-Русская сельскохозяйственная газета» («Dienvidkrievijas Lauksaimniecības Avīze»). Sākot no 1908. gada 15./16. numura, B. Jenkens kḷuva par tās zemstes vietējās sabiedriskās dzīves un valdības lēmumu nodalas vadītāju un pusgadu bija tās atbildīgais sekretārs. Šajā amatā viṇš nodemonstrēja izcilas nozares literatūras bibliogrāfa prasmes, īpaši tas attiecās uz selekcijas un sēklkopības vajadzībām. 1908. gadā šis žurnāls publicēja 21 viṇa rakstu un divas recenzijas. Nākamajā gadā avīze ievietoja $20 \mathrm{~B}$. Jenkena publikāciju - 15 rakstu un piecas recenzijas. No 1908. līdz 1918. gadam žurnāls nopublicēja 57 dažādus viṇa rakstus. Bez tam B. Jenkens 1908. un 1909. gadā uzrakstīja astoṇas publikācijas žurnālam «Хлебороб» (ukrainu valodā - lauksaimnieks). Liela to daḷa parakstīta ar kriptomīmiem B. K., B. E., B. un E. un ir veltīta izmēginājumu nozarei un labākai ieviešanai ražošanā. Citos rakstos autors informēja par jaunāko ārzemju pieredzi, informāciju tulkojot, - zinātnieks brīvi pārvaldỉja vācu un franču valodas, saprata arī angḷ valodu. Kādu laiku B. Jenkens veica redaktora pienākumus preses izdevumos «Хлебороб» un «Южно-Русская Сельскохозяйственная Газета» - pirmajā drukātajā izdevumā, kas Krievijas impērijā publicēja periodiskus un sistemātiskus selekcijas un sēklkopības literatūras apskatus. Turklāt no 1913. gada zinātnieks kḷuva par ikmēneša zinātniski sabiedriskā izdevuma «Агрономический журнал» («Agronomiskais Žurnāls») redakcijas locekli un tajā publicējās. Arī šo izdevumu izveidoja HLB. Vēl viña rakstus, parakstītus ar kriptomīmiem B. un E., publicēja izdevums «Сельскохозяйственный Вестник Юга-Востока» («Dienvidaustrumu Lauksaimniecības Vēstnieks») (1911-1914).

1914. gadā ar Lauksaimnieciskās augkopības komitejas atbalstu Harkovā norisinājās Krievijas impērijā pirmā apspriede par alus miežiem. B. Jenkens savā «Harkovas periodā» kḷuva par iniciatoru starpnieku biroja organizēšanā, kas nodarbojās ar aparātu un mašīnu pasūtīšanu un apkalpošanu [32]. Gan Lauksaimniecības augkopības komiteja, gan birojs kḷuva par obligātām struktūrvienībām visās lauksaimniecības stacijās.

\section{Darbība Krievijā un Ukrainā (1917-1943)}

Maz zināma ir B. Jenkena darbība Krievijas postimpērijā no 1917. līdz 1920. gadam. Nedaudz informācijas atrodam tā laika periodiskajos izdevumos, kuros B. Jenkens turpināja savu recenzenta un bibliogrāfa darbību. Te jāmin HLB un Centrālās Ukrainas Lauksaimniecības kooperatīvu savienības žurnāli «Хлебороб-Кооператор» (ukrainu valodā - «Lauksaimnieks-Kooperators»), «Сельский Хозяин» («Lauku Saimnieks») un «Агроном» («Agronoms»). Raksta autors 
ir atradis piecas viṇa rakstītās recenzijas par publikācijām, kurās apskatīta lauksaimnieciskās kooperācijas organizācija. Kas attiecas uz organizatorisko darbu, juceklis saimnieciskajā un administratīvajā dzīvē 1917. gadā un zemstu finanšu krīze 1918. gadā saasināja jautājumu ne tikai par nozaru institūciju funkcionēšanu, bet arī par izmēǵinājumu nozari kopumā. Situācijas analīzei Harkovas apgabala LIS 1918. gada 18. un 19. decembrī organizēja apgabala apspriedi veltītu izmēǵinājumu nozarei. Tajā ar ziṇojumu uzstājās arī B. Jenkens. Vinšs runāja par izmēǵinājumu nozares organizāciju un piedāvāja izveidot īpašu institūciju, kas apvienotu izmēǵinājumu iestāžu darbību reǵionā [2]. Tādējādi viņš pirmais izvirzīja domu, ka ir jābūt īpašai nacionālajai koordinējošai struktūrai nozares eksperimentālo uzñēmumu darbībai. Starp citu, šis B. Jenkena piedāvātais priekšlikums tika realizēts Ukrainā pēc pilnīgas padomju varas nostiprināšanās - ar Ukrainas Padomju Sociālistiskās Republikas Tautas komisāru Padomes 1921. gada 15. aprīla dekrētu [33]. Tika izveidotas lauksaimniecības izmēginājumu apgabalu pārvaldes Harkovas ar filiāli Poltavā, Kijevā, Jekaterinoslavskā un Odesā.

Augkopības komitejas vārdā, piedaloties Novoaleksandrijskas (mūsdienās - Polijas teritorija) lauksaimniecības un mežsaimniecības institūtam, Harkovas Universitātes Agronomijas nodal̦ai un Harkovas apgabala LIS, B. Jenkens iniciēja sēklkopības instruktoru sagatavošanas kursu izveidi, kurus atklāja 1919. gada pirmajā pusē [34]. Mācību laiks bija divi semestri: pirmais teorētiskais (no janvāra līdz martam), otrais praktiskais (no aprīḷa līdz septembrim). Labākajiem klausītājiem Zemkopības ministrija, zemstes un sabiedriskās iestādes piešķīra stipendijas. B. Jenkens sagatavoja kursu Statūtus un programmu. Šādi kursi bija pirmie Ukrainā. Pats B. Jenkens līdz pat savai aizbraukšanai uz Krasnodaras novadu vadīja kursus, lasīja lekcijas un vadīja praktiskās nodarbības.

Sakarā ar kārtējo veselības stāvokḷa strauju pasliktināšanos B. Jenkens no 1919. gada 19. jūlija līdz 1920. gada 17. maijam ārstējās Anapā, kur nodarbojās ar vīnogu audzēšanu un vīna darīšanu uz savas zemes sešām desetīnām. Pēc atvesel̦ošanās līdz 1921. gada 16. augustam vinš strādāja par speciālistu vīnogu audzētavā un dārzniecībā, vēlāk - par Agronomijas nodal̦as vadītāju Anapas rajona sovhozu pārvaldē. No 1921. gada 16. augusta līdz 1924. gada 1. decembrim B. Jenkens strādāja Krasnodaras novadā par selekcijas speciālistu un KubaṇasMelnās jūras apgabala zemes pārvaldes plānu komisijas sekretāru, no 1924. gada 5. maija - Krusas nodarīto zaudējumu apdrošināšanas nodaḷā par vadītāju; līdz 1924. gada 14. jūlijam - par vecāko apdrošināšanas inspektoru; līdz 1924. gada 20. decembrim - par lauksaimniecības pamatu lektoru un mācību lauku vadītāju Kubaṇas Augstākajā pedagoǵijskajā institūtā un līdz 1925. gada 10. janvārim - pedagoǵiskajā tehnikumā. Turklāt darba savienošanas kārtībā viṇš lasīja lekcijas 
Ziemeḷkaukāza Lauksaimniecības tehnikumā (no 1921. gada līdz tā slēgšanai 1922. gadā).

Agronoms B. Jenkens bija Kubaṇas novada pētījumu padomes Zinātniskās komitejas (vēlāk tā tika pārveidota par atsevišku zinātniskās pētniecības institūtu) un tās Lauksaimniecības sekcijas sekretārs, Selekcijas un sēklkopības apakšsekcijas priekšsēdētājs (1921-1924). 1923. un 1924. gadā vin̄š bija docents un mācīja selekciju un dạ̣̄jo zemkopību, kā arī lauku saimniecības pamatus Kubaṇas Lauksaimniecības tehnikumā. Līdz 1924. gada 3. jūlijam viṇš vadīja arī tā izmēǵinājumu lauku. Gadu B. Jenkens nostrādāja par selekcijas speciālistu Kubaṇas apgabala LIS selekcijas nodaḷā, pusgadu (pirms tā pārcēlās uz Rostovu) vadīja Kubaṇas-Černomorskas Valsts izdevniecības redakcijas kolēgijas Lauksaimniecības sekciju. Tā izdeva vairākas populārzinātniskas brošūras, kuru izdošanā iesaistījās agronoms.

Par galveno B. Jenkena Krasnodaras dzīves perioda un dailıades sasniegumu kḷuva elitāra sēklu audzētavas projekta izstrāde un daḷeji praktiska tā realizācija Anapā. Turklāt vinsš izveidoja sēklu organizācijas plānu Kubaṇā kopā ar Centrālo Valsts sēklu resoru, mātīšu audzētavu tīklu un škirṇu izmēginājumu laukiem, kā arī sēklu materiāla ražošanas un tirdzniecības valsts kontroles projektu. Savas atziṇas šajā sakarībā viṇš publicēja reǵionālajos periodiskajos izdevumos: «Красная звезда» («Sarkanā Zvaigzne»), «Сельскохозяйственная кооперация» («Lauksaimniecības Kooperācija»), «Памятка табаковода Кубани» («Kubaṇas Tabakas Audzētāja Instrukcija»), «Красное знамя» («Sarkanais Karogs») un citos, kā arī uzstājās ar referātiem organizatoriski pētnieciska rakstura profesionālās sapulcēs. Krievijas Agronomiskās biedrības Kuban,as nodaḷas uzdevumā viṇš vadīja redakcijas nodaļu un gatavoja tās žurnāla vairākus numurus, kas diemžēl līdzekḷu trūkuma dēḷ netika izdoti.

Vienlaikus ar zinātnisko darbību B. Jenkens nodarbojās arī ar sabiedrisko darbu: kā Anapas lauksaimnieku tehniķu profesionālās apvienības priekšsēdētājs piedalījās darba aizsardzības komisijas darbā (19201921) un tās Revīzijas komisijā. Vēlāk viṇš bija Kubaṇas-Černomorskas apgabala Zemes pārvaldes vietējās komitejas priekšsēdētāja vietnieks Krasnodarā (1921-1923). Sakarā ar abu dēlu un divgadīgās meitas diloṇa izraisīto nāvi B. Jenkenam nācās mainīt apstākḷus. Vēl jo vairāk tāpēc, ka Ukrainas valdība darīja visu iespējamo, lai etniskie ukraiṇi atgrieztos dzimtenē, radot viṇiem labvēlīgus apstākḷus. 1924. gadā Ukrainā atgriezās, piemēram, akadēmiķi Aleksejs Sokolovskis (Олексій Никанорович Соколовський; 1884-1959) [35] un Jevgēnijs Bobko (Євген Васильович Бобко; 1890-1959), lai veiktu zinātniski izglītojošo darbu Hristiāna Rakovska Harkovas Lauksaimniecības institūtā. Uz tā bāzes bija plānots 
atvērt L,eṇina Vissavienības Lauksaimniecības akadēmijas Ukrainas filiāli [36].

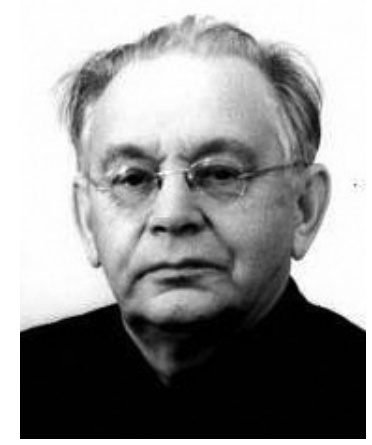

1924. gada 1. decembrī arī B. Jenkens atgriezās Ukrainā, kḷuva par Valsts maizes inspekcijas Odesas ostas un rajona galvenās laboratorijas vadītāju un tajā strādāja līdz 1925. gada 29. jūlijam. Šajā laikā vin,š apkopoja savu pētījumu rezultātus maizes zinātniskās klasifikācijas jomā, kā arī izstrādāja laboratorijas darbības metodologiskos pamatus. Pēc tam vin,š pārcēlās uz Harkovu, kur līdz 1925. gada 1. septembrim redigéja Ukrainas Sēklkopības biedrības biḷetenu, kā arī vadīja tās zinātnisko daḷu un muzeju [37]. Strādājot biedrībā, viṇš nosūtīja vēstuli botāniḳim N. Vavilovam ar lūgumu «n,emt savā paspārnē» viṇa dēlu Vadimu Jenkenu (Вадим Борисович Енкен; 1900-1981), kā arī aicināja sarīkot ceturto Vissavienības selekcijas un sēklkopības kongresu pēc analogiskā kongresa piemēra Harkovā 1911. gadā [38]. N. Vavilovs šo ideju atbalstīja. Sakarā ar amata likvidāciju B. Jenkens tika ievēlēts par Ukrainas Lauksaimniecības zinātniskās komitejas (tagad - Ukrainas Agrāro zinātṇu nacionālā akadēmija) zinātnisko sekretāru. Tajā pašā dienā komitejas Botāniskā sekcija ievēlēja viṇu par biedru, bet vēlāk - par Jauno kultūru un to introdukciju biroja priekšsēdētāju. Zinātnieks aktīvi piedalījās pētniecības darbā, ko veica kultūraugu apakšsekcija plavu kultūraugu botāniskās izpētes komisija. 1926. gada 1. decembrī viṇu pēc paša vēlēšanās atbrīvoja no zinātniskā sekretāra amata, taču B. Jenkens turpināja sadarboties ar kolēǵiem sabiedriskā kārtā. Piemēram, mēs varam viṇu atrast kultūraugu apakšsekcijas biedru vidū, kuru pienākumos ietilpa nodrošināt nozaru recenzēšanu un bibliogrāfisko darbu. B. Jenkena izvirzīšana atbildīgajā zinātniskā sekretāra amatā nebija nejaušība, jo viña profesionālisms un organizatoriskās spējas tika augstu novērtētas, kad viṇš pildīja komisijas priekšsēdētāja pienākumus rezervātā «Čapli» (patlaban - biosfēras rezervāts Askania-Nova), izstrādājot perspektīvu tā zinātniskās pētniecības plānu [39]. 
No 1926. gada 13. jūlija B. Jenkens amatu savienošanas kārtībā kḷuva par I grupas kvalifikācijas profesoru K. Timirjazeva vārdā nosauktajā Maslovskas šķirnu sēklu tehnikumā (tagad - Maslovskas Agrārais tehnikums) [40]. 1927. gada 1. oktobrī B. Jankens pārgāja uz pastāvīgu darbu minētajā mācību iestādē [41]. Agronoms vadīja arī Lauksaimniecības augu un produktu tehnisko īpatnību, pārstrādes un standartizācijas izpētes laboratoriju, ko viņš izveidoja 1926. gada 7. decembrī [42]. Vienlaikus B. Jenkens bija botānikas zinātniskās pētniecības katedras īstenais loceklis Harkovas Lauksaimniecības institūtā. Tajā viṇš nodarbojās ar jaunajām kultūrām. 1927. gadā B. Jenkens vadīja astoṇu cilvēku ekspedīciju, kas pētīja Ziemeḷkaukāza floras kultūru. Viṇa «Tehnikuma piezīmju» trešajam sējumam sagatavotie raksti - «Vietējo labības šķirṇu sastāvs» un «Par maizes ceptuvju un graudu miltu īpatnību laboratoriju» - netika publicēti. Vienlaikus viṇš vadīja arī redakcijas komisiju.

1927. gada 1. septembrī B. Jenkens sāka vadìt viṇa noorganizēto laboratoriju Kijevā, kurā tika pētītas graudu ìpatnības no miltu iegūšanas un maizes cepšanas viedokḷa. Lielā slodze nel̦āva B. Jenkenam pilnvērtīgi nodoties pedagoga darbam. Tāpēc 1928. gada 7. jūnijā viṇš iesniedza lūgumu par atbrīvošanu no darba tehnikumā, taču sadarbību ar to viṇš nepārtrauca [43]. Viṇa vadībā diplomandi veiksmīgi aizstāvēja kandidātu disertācijas selekcijas un graudkopības jomās. B. Jenkena vēl Harkovā radītās ziemāju rudzu šksirnes turpināja pētīt gan Maslovskas tehnikuma studenti, gan docētāji. Jāatzīmē, ka viṇš iemācīja selekcijas pamatus veselai tehnikuma studentu plejādei, kas vēlākos gados kḷuva par pasaules līmeña selekcionāriem. Vinu vidū ir Sociālistiskā Darba varoṇi, Lenina, Padomju Sociālistisko Republiku Savienības (PSRS) un Ukrainas Padomju Sociālistiskās Republikas Valsts prēmiju laureāti, akadēmiķi Prokofijs Garkavijs (Прокїn Хоми́ч Гарка́вий; 1908-1984), Fjodors Kiričenko (Федір Григорович Кириче́нко; 1904-1988), Vasīls Remeslo (Васи́ль Микола́йович Ремесло́; 1907-1983), profesori Mihails Olšanskis (Михаил Александрович Ольша́нский; 1908-1988), Pjotrs Škvarnikovs (Пётр Климентьевич Шкварников; 1906-2004) u. с.

Nozīmīgs ir B. Jenkena darbs Šķirņu sēklu pārvaldē. Pagājušã gadsimta 20. gadu otrajā pusē pārvaldes darbība bija ḷoti aktīva - tā bija valstiski nepieciešama jautājumos, kas skar labāko lauku kultūru šķirṇu iegūšanu (bietes, graudaugi, pākšaugi), sēklu pavairošanas apstākḷu izpēti un cukurbiešu kultūras izplatīšanu uz jaunajiem PSRS rajoniem. Ne mazāk svarīgs bija zinātniski organizatoriskais darbs entomoloǵijā, fitopatologijā un lauksaimniecības mikrobioloǵijā. Šiem mērķiem kalpoja piecas pētniecības stacijas, kas bija pakḷautas profilējošajam tautas komisariātam. Turklāt pēc Šḳirnuu sēklu pārvaldes iniciatīvas 1922. gadā Kijevas Politehniskajā institūtā tika dibināts Selekcijas zinātniskais institūts ar zinātniski pedagoğisku ievirzi, kuru vadīja profesors 
Volodimirs Kolkunovs (Володимир Володимирович Колкунов; 18661937). Par profesora galveno uzdevumu kḷuva cukurbiešu selekcijas metožu izstrāde. Tik intensīvs selekcijas un sēklkopības darbs ḷāva 1929. gada atteikties no cukurbiešu sēklu importa. Šajā procesā aktīvi piedalījās arī citas iestādes, tostarp minētā laboratorija Kijevā, kuru organizēja un vadīja B. Jenkens.

Finanšu problēmas, kas radās reorganizācijas procesu rezultātā Šķirnes sēklu pārvaldē pēc tam, kad 1927. gadā tika nodibināts Ukrainas cukura rūpniecības zinātniskās pētniecības institūts, iespaidoja arī zinātnieka B. Jenkena materiālo stāvokli. Viṇam bija jādomā par darbu un algu, lai kā vienīgais naudas pelnītājs uzturētu lielo ǵimeni (arī sievas vecākus, tanti ar brāḷameitu).

3. attēls. Boriss Jenkens (pa labi) ar sievu Lidiju Jenkens (Лидия Клавдиевна Єнкен) darba laikā Harkovas izmēǵinājumu stacijā [2].

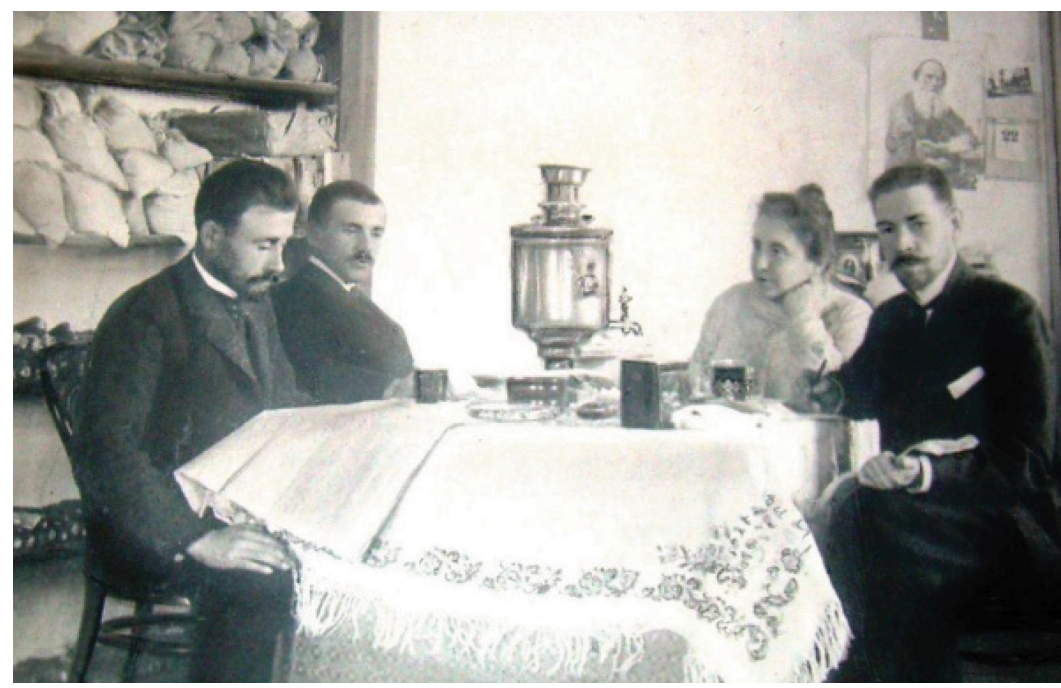

B. Jenkens 1928. gada vidū sāka strādāt par laboratorijas vadītāju Kijevā, Ukrainas Tirdzniecības muzejā, kurā pētīja miltu iegūšanas un maizes cepšanas procesus [44]. B. Jenkens tur radīja speciālu kolekciju pastāvīgai ekspozīcijai. Kā muzeja delegāts vinnš atkal tikās ar N. Vavilovu Vissavienības Genētikas, sēklkopības un vaislas lopkkopības kongresā, kas norisinājās no 1929. gada 10. līdz 16. janvārim L̦eniningradā [45]. Viṇš turpināja darbu muzejā, kuru 1929. gada beigās reorganizēja par Valsts zinātniskās pētniecības ekonomikas, tehnikas un racionālas tirdzniecības institūtu. 1930. gada sākumā B. Jenkens atgriezās darbā Harkovas apgabala Lauksaimniecības stacijā.

Politiskie procesi valstī ar tiem raksturīgajām safabricētajām apsūdzībām nevarēja neskart zinātnieku B. Jenkenu, turklāt bija sākušies viṇa kolēǵu aresti saistībā ar dalību «Ukrainas atbrīvošanas savienībā» 
un «Laucinieku darba partijā». No 144 arestētajiem 50 bija dažādu nozaru zinātnisko institūtu un staciju līdzstrādnieki [46]. Ar daudziem apcietinātajiem B. Jenkens bija pazīstams un uzturēja draudzīgas attiecības.

Ģimenes apstākḷu dēḷ - viṇa dēls Vadims pēc Kubaṇas Lauksaimniecības institūta agronomijas fakultātes absolvēšanas (1925) tika nosūtīts uz Kubaṇas augkopības izmēginājumu staciju, kas atradās Botānikas ciemā Krasnodaras novadā, kur sāka savu karjeru vecākā laboranta, bet beidza direktora amatā [47]. B. Jenkens bija spiests atgriezties Kubaṇas Lauksaimniecības institūtā (tagad - Kubaṇas Valsts agrārā universitāte), kur viṇš jau kādreiz bija strādājis. Pēc tam, kad 1930. gadā tika arestēts pirmais 1926. gadā dibinātās Selekcijas un sēklkopības katedras vadītājs docents Vasilijs Pustovoits, kas vēlāk kḷuva par pasaules līmeña selekcionāru, akadēmiḳi, L,eņina un Valsts prēmiju laureātu, divkārtējo Sociālistiskā Darba varoni, B. Jenkens kḷuva par katedras vadītāju [48]. 1933. gadā veselības problēmu dēl viṇš bija spiests no amata aiziet, vispirms kḷustot par katedras profesoru, bet vēlāk, no 1935. gada, viṇš vadīja Kubannas izmēǵinājumu stacijas zinātnisko bibiotēku [49]. Stacijā B. Jenkens pēdējo reizi tikās ar akadēmiksi N. Vavilovu, kad vinšs 20. gadsimta 30. gadu vidū apmeklēja izmēǵinājumu laukus. Akadēmiķis toreiz apciemoja Jenkenu ǵimeni, un Jenkena mazmeita joprojām atceras zinātnieka dāvināto krāšn,o konfekšu kasti.

Otrā pasaules kara sākumā B. Jenkens cienījamā vecuma un slimības dēl kopā ar gimeni un izmēginājumu stacijas kolektīvu naktī uz 1942. gada 4. augustu nedevās evakuācijā uz Krasnoufimsku Sverdlovskas apgabalā. Okupētajā teritorijā viṇš darīja visu iespējamo, lai garnizona komendants nedotu pavēli iznīcināt ciemu Otrada Kubanskaja un izmēǵginājumu staciju, un par šiem jautājumiem runāja, tiekoties ar vācu komandējošā sastāva pārstāvjiem. Pirms tam viṇš un sieva tika apcietināti, un Jenkeniem draudēja nošaušana, jo kāds bija sniedzis nepatiesas ziṇas. No apcietinājuma vinu ar sievu atbrīvoja tikai tāpēc, ka viṇš uzrādīja pasi ar ierakstu, ka viṇš ir vācu tautības. 1943. gada marta sākumā izmēginājuma stacija atjaunoja savu darbību Borisa Jenkena dēla Vadima Jenkena vadībā.

B. Jenkens nomira 1943. gadā, atdusas Otradno-Kubanskas kapsētā Botānikas ciemā. Daudzo gadu pētniecības darbs, kura rezultāti ir apkopoti 2014. gadā izdotā monogrāfijā [50], ir ḷāvuši noskaidrot, ka izcilā zinātnieka B. Jenkena radošajā mantojumā ir 127 zinātniskie un populārzinātniskie darbi, brošūras, recenzijas krievu un arī ukraiṇu valodā. Tie tapuši no 1905. līdz 1926. gadam. Diemžēl viṇa vēlākās publikācijas pagaidām autoram nav pieejamas. Sevišķi tas attiecas uz viṇa Krasnodaras dzīves un daiḷrades periodu (1919-1924; 1930-1943). Iespējams, ka 
zinātnieka publikācijas atrodas ārzemēs. Pārskatot publikācijas, jāsecina, ka B. Jenkina zinātniskās intereses bija daudzveidīgas - augkopība, selekcija un sēklkopība, geogrāfiskie pētījumi, sabiedriskā agronomija, lauksaimnieciskā bibliogrāfija un lauksaimniecisko izmēǵinājumu prakses vēsture. Zinātnieks 1925. gadā rakstīja, ka speciālus zinātniskus sacerējumus nav sagatavojis slimību dēḷ un tāpēc nav spējis apkopot visu paveikto, galvenokārt - Harkovas LIS. Viṇaprāt, zinātnisku sacerējumu statuss piemita tiem viṇa referātiem, kas tika publicēti dažādu profesionālu kongresu un konferenču materiālos. Iepazīstoties ar tiem, tiešām var secināt, ka B. Jenkens ir bijis l, loti zinošs jautājumos, kas attiecas uz nacionālās lauksaimnieciskās izmēǵinājumu prakses organizāciju, īpaši tas attiecas uz selekciju un sēklkopību.

Tēva darbu veiksmīgi turpināja viṇa dēls Vadims Jenkins - lauksaimniecības zinātṇu doktors, profesors, Krievijas Padomju Federatīvās Sociālistiskās Republikas Nopelniem bagātais zinātnes un tehnikas darbinieks. Viṇš ir autors 12 rajonētām sojas, miežu šķirnēm, ir publicējis apmēram 100 zinātnisku sacerējumu, to skaitā 10 brošūru, grāmatas un monogrāfijas par graudaugu kultūrām [51]. V. Jenkena 1959. gadā izdotā monogrāfija «Соя» («Soja», 1959) līdz šim brīdim tiek uzskatīta par labāko gan Krievijā, gan ārzemēs. Vectēva un tēva pēdās ir sekojušas B. Jenkena mazmeitas Olga un Tatjana, kuras ir aizstāvējušas kandidāta disertācijas agrobioloǵijā [52].

Rezumējot vairāk nekā 10 gadu zinātniskā pētījuma rezultātus par B. Jenkenu, jāsecina, ka vinšs kā Krievijā dzimušais, bet dvēselē - Ukrainas vācietis, A. Fortunatova līdzgaitnieks, P. Budrina skolnieks, N. Vavilova kolēǵis jāierindo izcilāko Ukrainas zinātnieku vidū, īpaši, akcentējot viña ieguldījumam lauksaimniecības augu selekcijā. Pateicoties B. Jenkenam, Ukrainā augstā līmenī ir attīstījusies lauksaimnieciskā izmēǵinājumu prakse. Pirmo izmēǵinājumu lauku pirms 134 gadiem Poltavā atklāja V. Dokučajevs (В. В. Докучаев), bet par vienu no neapstrīdamiem selekcijas celmlaužiem ir uzskatāms B. Jenkens [53].

B. Jenkena mūža devums un darbība atspoguḷota enciklopēdiskos izdevumos, publikācijās, 2014. gadā ar raksta autora gādību tika atklāta viṇam veltīta memoriālā plāksne pie Maslovskas Agrārā tehnikuma fasādes. 


\section{AVOTU UN LITERATŪRAS SARAKSTS}

[1] Latvijas Valsts vēstures arhīvs (LVVA) 7175. f., 1. apr., 1904. l., 145. lp.

[2] Vergunov, V. A. Professor Jenken Boris Karlovich (1873-1943)-uchenyy, selektsioner, pedahoh, orhanizator suspilnoyi ahronomiyi ta vitchyznyanoyi silskohospodarskoyi doslidnoyi spravy: nauk. dop. / NAAN, NNS·HB. Kyyiv: FOP Korzun D.Y., 2014, s. 15-16.

[3] Tsentralnyy gosudarstvennyy arkhiv vysshikh organov vlasti i upravleniya (CGAVO) Ukrainy f. 27, op. 17 l, d. 1395, l. 9.

[4] The State Archives of Vinnytsia Region fund 15, description 1, thing 5, p. 2.

[5] CGAVO Ukrainy f. 166, op. 12, d. . 2416, l. 7.

[6] LVVA 7175. f., 1. apr., 1905. l., 134. lp.

[7] Materiali agronomicheskogo soveshchaniya pri Saratovskoy gubernskoy uprave, 27 iyulya 1902 g. Saratov: Tip. T-va G.KH. Shelgorka i Ko, 1902.

[8] State Archive of Tambov oblast f. 145, op. 1, d. 2396, l. 179, 251 ob.

[9] State Archive of Tambov oblast. Arkhivnaya spravka No. 2551/06 from 20.08.2012, p. 1-2.

[10] Gosudarstvennyy arkhiv Kharkovskoy oblasti (GAKO) f. 3, op. 287, d. 4372, l. 12-13.

[11] Pryanishnikov, A. I. Sto let v nauchnom poiske. Agrarnyy vestnik Yugo-Vostoka, 2010, Nr. 2 (5), s. 42.

[12] Album Academicum des Polytechnikums zu Riga, 1862-1912. Riga: Jonck\&Poliewsky, 1912, S. 320.

[13] K zakladke glavnogo zdaniya Kharkovskoy selektsionnoy stantsii. Yuzhno-Russkaya selskokhozyaystvennaya gazeta, 1909, No. 25-26, S. 10-12.

[14] GAKO f. 3, op. 287, d. 4372, l. 12-13.

[15] B. E. [Jenken B. K.] Iz deyatelnosti Kharkovskogo obshchestva selskogo khozyaystva. Yuzhno-Russkaya selskokhozyaystvennaya gazeta, 1909, No. 5-6, s. 21.

[16] Narodnaya entsiklopediya nauchnykh i prikladnykh znaniy. T. 4: Selskoye khozyaystvo. Polutom 2: Zemledeliye / Khark. o-vo rasprostraneniya v narode gramotnosti; red., avt. predisl. P. V. Budrin. Moskva: Tip. t-va I. D. Sytina, 1910, XVIII, s. 357-850.

[17] Jenken, B. K. itogam pervovo Vserossiyskogo selektsionnogo syezda. Selskokhozyaystvennyy vestnik Yugo-Vostoka, 1911, No. 2, s. 14-16.

[18] Trudy pervogo syezda deyateley po selektsii selskokhozyaystvennykh rasteniy, semenovodstvu i rasprostraneniyu semennogo materiala 10-15 yanvarya 1911 g. v g. Kharkov. Vyp. II: Doklady / pod red. Komiteta v sost. P. V. Budrina, A. A. Potebni, B. N. Rozhestvenskogo, L. P. Sokalskogo. Kharkov: Tip.-lit. M. H. Sergeyeva i K. M. Galchenka, 1911, S. 85-94, 107-139, 309-338.

[19] Iz deyatelnosti Kharkovskogo obshchestva selskogo khozyaystva. Yuzhno-Russkaya selskokhozyaystvennaya gazeta, 1911, No. 6, s. 17. 
[20] Jenken, B. Chetvertaya geneticheskaya mezhdunarodnaya konferentsiya v Parizhe (Korrespondentsiya iz Parizha). Selskokhozyaystvennyy vestnik Yugo-Vostoka, 1911, No. 20, s. 12-13.

[21] Jenken, B. K. Pisma iz zagranitsy (Zametki selektsionera). Kharkov: Khark. O-vo sel. khoz-va, 1912, $32 \mathrm{~s}$.

[22] Russian State Historical Archive f. 382, op. 9, d. 217, 1. 107.

[23] Oblastnoy syezd po selektsii i semenovodstvu v Peterburge. Izvestiye Glavnogo upravleniya zemleustroystva i zemledeliya, 1912, No. 5, s. 115-116.

[24] Fabrikant, A. Kratkiy obzor deyatelnosti syezda po opytnomu delu Yugo-vostoka Yevropeyskoy Rossii i Severnogo Kavkaza, 24-26 maya 1912 g. Trudy 1-go syezda po selskokhozyaystvennomu opytnomu delu Yugo-vostoka Rossii i Severnogo Kavkaza, 24-26 maya 1912 g. Rostov-na-Donu, 1913, s. 17.

[25] Komissiya po sortovedeniyu. Vtoroye zasedaniye 12-go fevralya. Trudy soveshchaniya po selskokhozyaystvennomu opytnomu delu, proiskhodyashchego 10-17 fevralya 1913 g. pri Glavnom upravlenii zemleustroystva i zemledeliya. Petrograd: Tip. Red. period. izd. Min-va finansov, 1914, Vyp. II, s. 165.-169.

[26] Sostoyashchaya pod Avgusteyshim Pokrovitelstvom Yego Imperatorskogo Vysochestva Naslednika Tsesarevicha i Velikogo Knyazya Alekseya Nikolayevicha Vserossiyskaya vystavka, g. Kiyev, 1913 g. Kiyev: Foto-lito-tip. S. V. Kulzhenko, 1913, s. 53.

[27] Trudy 1-go Vserossiyskogo selskokhozyaystvennogo syezda v Kiyeve 1-10 sentyabrya 1913 g. Vyp. V: Zhurnaly zasedaniy sektsii zemledeliya i doklady sektsii / pod red. I. G. Chernysha, I. A. Prilezhayeva. Kiyev: Tip. A. M. Ponomareva, 1914, s. 18., 22.

[28] Bor. Karl. Jenken. Mestnyy agronomicheskiy personal sostoyashchiy na pravitelstvennoy i obshchestvennoy sluzhbe 1 yanvarya 1914 g.: spravochnik / sost. N. A. Aleksandrovskiy, M. M. Gaukhov. N. R. Shcherbakov, pod obshch. red. V. N. Shteyna; GUZiZ, Departament zemledeliya. Petrograd: Tip. V. F. Kirshbauma, 1914, s. 383.

[29] Lokhvitskoye opytnoye pole. Kultura tabaka-makhorki i maslichnykh / sost. G. I. Zhukov. Lokhvitsa: Tip. N. B. Delberga, 1913, s. 5, 12, 17.

[30] Kalaydzhan, A. A, Khlevnoy L. V., Neshchadim N. N. [i dr.]. Rossiyskiy solnechnyy tsvetok. Ros. akad. s.-kh. nauk, Kub. nar. akad. Krasnodar: Sovet. Kuban, 2007, 332 s.

[31] Kyrychenko, V. V., Humenyuk, A. D., Ozhereleva, V. M. Yenken Borys Karlovych. Yuryivska shkola roslynnykiv. Nauk. vyd. / In-t roslynnytstva im. V.YA. Yuryev UAAN. Kharkov: Magda «LTD», 2008, s. 76.

[32] M. Ye. Oblastnoye soveshchaniya po opytnomu delu 18 i 19 dekabrya v Kharkove. Yuzhno-Russkaya selskokhozyaystvennaya gazeta, 1918, No. 2, s. 11.

[33] CGAVO Ukrainy f. 27, op. 3, d. 7, 1. 164-165.

[34] Kursy dlya podgotovki instruktorov po semennomu delu. Yuzhno-Russkaya selskokhozyaystvennaya gazeta, 1918, No. 2, s. 11. 
[35] Vergunov, V. A., Novosad, N. M., Zozulya, V. A., Novosad, K. B. Akademik Sokolovskyy Oleksiy Nykanorovych: zhyttyevyy shlyakh ta naukova diyalnist (prysvyach. do 50-richchya z dnya zasnuvannya Nats. nauk. tsentru «IHA im. O. N. Sokolovskoho» i 60-richchya z dnya zasnuvannya fakultetu ahrokhimiyi ta gruntoznavstva KHNAU im. V. V. Dokuchayeva). Kharkiv: K. P. «Druk No. 13», 2006, 164 s.

[36] Postanovlenije Pervovo Syezda Sovetov Soyuza Sovetskikh Sotsialisticheskikh Respublik. 1-y Syezd Sovetov Soyuza Sovetskikh Sotsialisticheskikh Respublik (stenogr. otchet s pril.). Moskva: TSIK SSSR, 1922, s. 8.

[37] Otchet o deyatelnosti Vseukrainskogo obshchestva semenovodstva s 1 aprelya po 31 dekabrya $1922 \mathrm{~g}$. Kharkov, 1923, s. 9.

[38] B. K. Jenkenu. 3 dekabrya 1925 g. Nauchnoye nasledstvo. Moskva: Nauka, 1980, t. 5. Nikolay Ivanovich Vavilov (iz epistolyarnogo naslediya 1911-1928 gg.), s. 243-244.

[39] CGAVO Ukrainy f. 1230, op. 1, d. 3, 1. 65.

[40] CGAVO Ukrainy f. 166, op. 12, d. 2416, l. 10.

[41] CGAVO Ukrainy f. 166, op. 6, t. 3, d. 4489, l. 30.

[42] CGAVO Ukrainy f. 166, op. 6, t. 3, d. 4491, l. 80.

[43] CGAVO Ukrainy f. 166, op. 6, t. 3, d. 4490, l. 19.

[44] Kyyiv. Providnyk / za red. F. Ernsta; NKO USRR, VUAN. Куyiv, Київ. 1930.

Pieejams: http://www.alyoshin.ru/Files/publika/ernst/ernst_kyiv_167. html [skatîts: 19.04.2018].

[45] Spisok uchastnikov Vsesoyuznogo syezda po genetike, selektsii, semenovodstvu i plemennomu zhivotnovodstvu v Leningrade 10-16 yanvarya $1929 \mathrm{~g}$. Leningrad: Izd-vo redakts. Kollegii syezda, 1929, t. 1, s. 149.

[46] Sprava «Ukrayinskoyi filiyi Trudovoyi selyanskoyi partiyi» (uporyad.: T. F. Hryhoryeva, V. I. Ocheryatenko). Kyyiv: Holov. redkol. «Reabilitovani istoriyeyu», 2010, s. 10-11.

[47] Goncharov, N. P. Vadim Borisovich Jenken: к 110- letiyu so dnya rozhdeniya. Vavilovskiy zhurnal genetiki i selektsii, 2011, tom 15, No. 1, s. 184.

[48] Zelenskiy, G. «Standing at the source», Part 2 (From History of department of Genetic, Breeding and Seed-growing of Kuban State Agrarian University). Nauchnyy zhurnal KubGAU, 2011, No. 67 (03), s. 1.

[49] Gosudarstvennoye nauchnoye uchrezhdeniye «Vserossiyskiy nauchno-issledovatelskiy institut risa RASKHN». Arkhivnaya spravka No. 01-22/1184 ot 22.10.2012, s. 1.

[50] Vergunov, V. A. Professor Boris Karlovich Jenken (1873-1943): narys zhyttya ta tvorchoyi diyalnosti. Kyyiv: TOV «Nilan-LTD», 2014, $432 \mathrm{~s}$.

[51] Shchelko, L. G. Vadim Borisovich Jenken. Soratniki Nikolaya Ivanovicha Vavilova. Issledovateli genofonda rasteniy. Sanktpeterburg, 1994, s. 162.

[52] Goncharov, N. P. Vadim Borisovich Jenken: к 110-letiyu so dnya rozhdeniya. Vavilovskiy zhurnal genetiki i selektsii, 2011, tom 15, No. 1, s. 183-192.

[53] Vergunov, V. «Ukrayinski etyudy» z poltavskym aktsentom v zhytti i diyalnosti profesora Borysa Jenkena (do 150-richchya Poltavskoho tovarystva silskoho gospodarstva). Vechirnya Poltava. 2015. 4 lyut. [No. 5 (1145)], s. 5-6; 6 lyut. [No. 6 (1146)], s. 6; 18 lyut. [No. 7 (1147)], s. 6. 


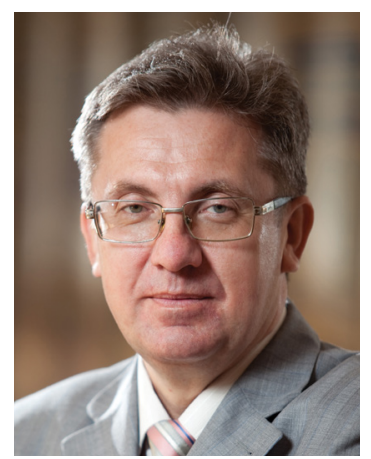

VICTOR VERGUNOV, Doctor of agricultural sciences, Professor, Academician of the National Academy of Agrarian Sciences of Ukraine, director of the National Scientific Agricultural Library of the National Academy of Agrarian Sciences of Ukraine, head of the Institute of History of Agrarian Science, Education and Technology. His research interests include the history of the agricultural experimental work in the Ukrainian lands, agricultural science and education in Ukraine.

Address: 10 Heroiv Oborony Street, Kyiv, Ukraine, 03127

Phone: +380679985975

E-mail:nnsgb@ukr.net

\section{Graduate of Riga Polytechnic Institute, agronomist Boris Jenken (1873-1943)}

The article is dedicated to the life and creative heritage of the graduate of the Riga Polytechnic Institute (RPI; 1900) agronomist Boris Jenken (Борис Карлович Єнкен; 1873-1943). B. Jenken was an organizer, scientist, breeder, educator, historian and bibliographer of agrarian science of the Ukrainian national agriculture. The study was carried out using not well-known and recently distributed documents for use in the archives of the Russian Federation and the Ukraine, as well as monographs and publications in periodicals. The article analyses the life and activity periods of the researcher related to the organization and implementation of national agricultural trials, mainly in the field of breeding and seed growing. The emphasis was placed on B. Jenkens' scientific and pedagogical work in the Ukraine: in Kharkov (1908-1919; 19251926; 1930), Odessa (1924), Maslovka (1927-1929), and Kyiv (1928-1929).

Keywords: Riga Polytechnic Institute, Boris Jenken, agronomy in the first half of the 20 th century in Ukraine.

\section{Виктор Анатольевич Вергунов}

\section{Выпускник Рижского политехнического института агроном Борис Енкен (1873-1943)}

Статья посвящена жизни и научному наследству выпускника (1900) Рижского политехнического института агронома Бориса Енкена (1873-1943). Он был организатором национального сельского хозайства Украины, а также известен как ученый-селекционер, педагог, историк и библиограф аграрной науки. Исследование проведено с использованием малоизвестных и только открывшихся для широкого пользования документов с архивов Российской Федерации и Украины, а также доступных публикаций с периодических и монографических изданий. В статье рассмотрены отдельные периоды жизни и деятельности ученого о вопросах 
организации и ведения отечественного сельскохозяйственного опытного дела, в первую очередь для потребностей селекции и семеноводства. Основное внимание автора сосредоточено на научно-образовательной деятельности Б. К. Енкена на украинских землях: в Харькове (1908-1919, 1925-1926, 1930), Одессе (1924), Масловке (1927-1929) и Киеве (1928-1929).

Ключевые слова: Рижский политехнический институт, Борис Енкен, агрономия в первой половине XX века в Украине. 